\title{
Recruitment and Selection Practices of Construction Employers in Rwanda
}

\author{
Oluwaseun Sunday Dosumu ${ }^{1 *}$, Philip Olayemi Lawal ${ }^{1}$, Consolatrice Uwineza ${ }^{1}$, Philippe \\ Mugiraneza $^{1}$, Eric Dushimiyimana ${ }^{1}$ and Marius Ruzindana ${ }^{1}$ \\ ${ }^{1}$ Department of Construction Management, School of Architecture and Built Environment, College of Science \\ and Technology, University of Rwanda, P.O. Box 3900, Kigali, Rwanda. \\ *Corresponding Author: oluwaseundosumu97@gmail.com \\ DOI: $10.4314 /$ rjeste.v4i1.8 \\ https://dx.doi.org/10.4314/rjeste.v4i1.8
}

\begin{abstract}
Human resources play a key role in the achievement of construction projects. This study investigated the recruitment practices of construction employers in Rwanda. The problem of the study is the lack of empirical evidence to support the recruitment and selection practices of construction employers in Rwanda. Similar studies are abundant in other sectors of the economy but very scarce in the construction industry. The descriptive survey research design was adopted for the study. A closed-ended questionnaire was used for data collection. The population of the study are the construction organisations that employ construction workers in Rwanda. Hence, the population of the study is the 580 construction organisations that are officially working in Rwanda. A sample of 80 firms used for the study were determined with the use of Slovin's formula. The findings of the study indicated that requests for the curriculum vitae, cover letter, face-to-face interview, submission of applications with key information of education/work experience and knowledge test to measure job specific knowledge are the prevalent strategies of recruiting and selecting staff in the construction industry. The prominent sources of recruitment and selection are internship performance, internal advertisement, and local newspaper advertisement. Based on the findings of the study, it was recommended that construction organizations should study and adopt the recruitment and selection strategies that have given them the most effective results. It was also recommended that the organisation should stick to the most effective sources of recruitment and selection for their organisations
\end{abstract}

Keywords: Construction organisation, sources of recruitment, Kigali, construction workers, recruitment methods 


\section{Introduction}

The construction industry is one of the key measures by which the economy of a nation is estimated. This is because the construction industry is an important division of national financial development like other industries such as agriculture, manufacturing and services. Hence, for the success of any country, construction is critical and ought to be supported by all stakeholders. In Rwanda, the National Institute of Statistics, Rwanda (2019) noted that services which include the real estate and construction industry accounts for 53\% of the total Gross Domestic Product (GDP).

However, like other sectors in Rwanda, the construction industry faces numerous challenges that hamper its development and performance. The construction industry in Rwanda is faced with design, financial, technological, human resource and productivity challenges among others (MININFRA, 2015). Among these challenges, human resource and productivity were highly impactful and related to the types of workforce engaged by an organization. Workforce is the most valuable commodity of an organisation and this implies that the success of a construction organisation is directly related to its type of human resources.

Therefore, it is important that construction organisations select individuals with relevant quality and qualifications in order to remain competitive in business. The main method of achieving this is the adoption of appropriate recruitment and selection practices (Schuler and Jackson, 1987). This indicates that there is a strong connection between workforce and industry performance. Hence, there is a need to put conscious effort into the process of recruitment and selection of workforce. The problem of this study is the lack of adequate empirical information on how workers are recruited and selected by construction employers in Rwanda.

An effective recruitment and selection process helps a construction firm to hire the right individual for a particular job or position. It was noted that most construction companies in Rwanda do not follow their firm's recruitment and selection processes in the appropriate manner. LMIS (2010) noted that many construction firms in Rwanda ignore standard selection programs, and this makes selection of personnel overwhelmingly loaded with unethical practices such as bias, discrimination and favouritism. Yet, firms with inappropriate recruitment and selection processes experience high labour turnover, high staff absenteeism, jobs rework, high training expenses, labour unrest, project delays and low productivity 
(Djabatey, 2012). These affect construction organisations and projects and may even lead to project failures in many instances.

Therefore, this study was intended to assesses the prevalent recruitment and selection strategies adopted by construction companies, the prominent sources of recruiting and selecting employees in the construction industry and the effectiveness of the sources of recruiting and selecting employees in the construction industry.

\section{Literature review}

There is inadequate information on how recruitment and selection processes of employees are done in the Rwandan construction industry. There have been many research studies on the recruitment and selection of employees into various sectors of the economy such as banking, oil and gas, manufacturing and telecommunication. However, similar researches on recruitment and selection into construction organisations and industry are scarce. This may be one of the key reasons for the inefficiencies among employees in the construction industry.

Adienge et al (2018) compared the relationship between internal recruitment of staff and performance with the relationship between external recruitment of staff and performance in Kenya. The study concluded that, internal recruitment was strongly and significantly correlated with the prices of services provided by the county governments and both internal and external recruitment had no significant relationship with perceived quality of service at the counties. Similarly, Djabatey (2012) examined how recruitment and selection practices affect the performance of HFC Bank, the challenges associated with the recruitment and selection practices of HFC Bank, and factors that could improve recruitment and selection practices at HFC Bank. The result of the study indicated that the bank had structured ways of selecting new employees. It also found that, potential employees must have the necessary education before being qualified for interview.

Furthermore, Lushiku (2014) examined the effectiveness of recruitment and selection procedures in the public sectors using Tanzania Revenue Authority (TRA) as case study. The result of the study indicated that the recruitment and selection process at the TRA were not effective enough as they contained a number of challenges which have negative impact on the whole selection process. It was equally found that, the main militating factor of its ineffectiveness was involvement in long recruitment and selection procedures compared to 
what has been indicated on the TRA recruitment manual. Janes (2018) assessed the challenges facing recruitment, selection and retention process in small industries in Mwanza region and discovered that the struggle to maintain effective recruitment, selection and retention process is a major issue facing the industries in Mwanza region. Hence, the key challenges of recruitment and selection were lack of recruitment and selection plans, lack of effective recruitment, lack of selection and retention policies and procedures, changes in recruitment technology, and use of old and ineffective recruitment, selection and retention methods.

Ekwoba et al. (2015) examined the effect of recruitment and selection criteria on the performance of staff in Fidelity Bank Plc. The study found that, out of the identified recruitment and selection methods, the most frequently used were newspaper advert, in-house (internal recruitment), labour office, employee referrals, radio advertisement and internet recruitment. The study recommended that the objectives of management for recruiting workers must be reviewed in order to avoid critical failures despite the existing recruitment and selection policy. In addition, the top barriers to the use of chosen recruitment and selection method were poor human resource (HR) planning, ineffective job analysis, competency level on the part of employee, cost of recruitment and selection of employees, lack of human resource department and poor working condition of workers.

From the studies reviewed, it is evident that there are scarce studies on how employees are recruited and selected for construction organizations and projects especially in Rwanda. Many of the studies investigated focused on other sectors and not the construction industry. Without a study of this nature, the continual problem of poor employee performance/productivity which eventually leads to poor project performance may continue to bedevil the construction industry. Hence this study is required to complement existing scarce resources on recruitment and selection of employees in the construction industry. It is also required to determine the appropriate procedures for recruiting and selecting employees into construction industry with a view to improving project performance. Therefore, the problem of this study is the lack of knowledge of the recruitment and selection procedures for employees in the Rwandan construction industry.

From literature, the stages involved in the process of recruitment and selection of employees were identified to include; Identification of hiring need, Planning (Cuming, 1994), Creation of job description, Job advertisement, Screening (Nel et al. 2009), References and background 
checks (Mathis and Jackson, 2006), Written examination test (Gomez-Majia et al. 2004), Interviews (Transley et al., 2001; Wilkinson, 2004; Mavis, 2014), Physical tests (Narayana, 2012), and Decision making and Job offer (Prasad 2006). Furthermore, twenty two strategies of recruiting and selecting employees were elicited for this study from researches on various sectors of national economy. These strategies among others include; careful screening of job applicants, maintenance of good relationship with previous employees of the firm previously (Langseth, 1995), giving of value to potential employees' references and previous employments (Odiorne, 1984), Informing the surrounding community about the plan to recruit (Prashant, 2009), creation of the right job posting which includes details of the type and quality of skills required (Mathis and Jackson, 2006), Building of applicants' pool/employee referral program (Jyoth, 2006), Improvement of organisation's interviewer skills (Hornberger, 1998), and hiring from a Broad Range of Background (Cuming, 1994).

Other strategies are; hiring from Internal applicants, evaluation of training and experiences through provision of checklist, personal profile or biographical data checking, asking for curriculum vitae along with application, submission of applications with key information of education/ work experience, knowledge tests to measure the job-specific knowledge, personality and interest test, performance test under structured challenging circumstances, behavioural interviews to ascertain specific skills, face to face individual interview, group interview, description and justification of applicable recruitment method, and medical examination to test physical fitness (Jyoth, 2006).

Furthermore, twenty sources of recruitment and selection (classified into two) were obtained from literature and used for this study. The two classifications of the sources of recruitment and selection are; internal sources (promotions (Sherman et al. 1998); transfers and internal advertisement (Keshav, 2013)). The external sources are advertisement (Rajarao, 2010), educational institutions (Nel et al. 2009), Recommendation of existing employees (Rajarao, 2010), walk-in interviews, e-recruitment (Cappelli, 2001; Nel et al. 2009), and former employees (Brake and Lawrence, 2000)). Other sources of recruitment and selection include employee referral, campus recruitment, promoting, recruitment offices/advisors, work destinations/entries, and organisation's sites (Sinha and Thaly, 2013). It is important to note that many organisations employ more than one of these methods at the same time for the recruitment and selection of employees. The effectiveness and the level of use of these sources are determined by the advantages and disadvantages of adopting each of the methods. 
For instance, it was affirmed that the internal sources of recruitment and selection promote loyalty, boosts workers' morale, encourage self-development (Sunderland and Canwell, 2008), results in lower training cost (Lushiku, 2014), and ease of finding the right candidate for a job (Duggan and Croy, 2004). Its disadvantages include limitation of the sources of job supply, implementation of the traditional system of recruitment for an organisation (Keshav, 2013), and preclusion of job opportunities for young and new talents (Sunderland and Canwell, 2008). In the same vein, external sources of recruitment and selection open an organisation to a bigger pool of candidates (Duggan and Croy, 2004), enables an organisation to focus on key players that make competition fruitful (Armstrong and Barron, 1998), could inspire in-house workers to accomplish more with expectations of getting the limited internal opportunities, opens up the chances to exceptionally qualified candidates, and fairness of recruitment, and gives opportunity to get ideas from other businesses or industries (Robins, 1994). Despite these advantages, external sources of recruitment and selection build expenses through press and preparation to accommodate new candidates, time-consuming recruitment process (Rotella, 2000), lack of adaptability to work environment, possibility of non-cooperation between the new and old staff since old staff may feel that their privilege has been grabbed by the new staff.

\section{Research methodology}

The quantitative descriptive research technique was used in this study. A cross sectional survey was adopted for data collection in this study using a closed-ended questionnaire. The questionnaire has two sections which are the general section and specific section. The general section collected the demographic information of respondents and their organisations. The specific section collected information on the recruitment and selection strategies adopted by construction companies, the sources of recruiting and selecting employees and the effectiveness of the sources of recruiting and selecting employees in the construction industry.

The population of this study are the personnel responsible for recruitment and selection of employees in construction organisations in Rwanda. According to the Rwanda Housing Authority (2015), there are 580 private constructions companies in Rwanda. Hence, the population of the study is the 580 construction organisations that are identified to exist in Rwanda.

The sample size for the study was calculated using the Slovin's formula: 
$\mathrm{n}=\mathrm{N} /\left(1+\mathrm{Ne}^{2}\right)$

Where $\mathrm{n}$ is the sample size, $\mathrm{N}$ is the population and e is the margin of error $(10 \%)$. The sample size for the study was therefore found equal to 84 .

The study was based on the assumption that all the construction organisations in Rwanda employ construction workers. Hence, there was no need for classifying the organisation based on size, turnover and number of employees among others. Therefore, the simple random sampling technique was used to arrive at the sample size after using the table of random numbers.

As earlier stated, the data collection instrument for the study was the close-ended questionnaire which was divided into two sections. Section 1 contained the demographic data of the respondents and their organisation and section 2 contained specific questions that related to the recruitment and selection of employees by construction organisations. The data for this study were basically analysed with descriptive statistics such as frequency, sums, mean item score and standard deviation. The results of the study were presented with tables and bar charts from the Microsoft excel software.

\section{Result and analysis}

The data analysis for this study was presented in this section of the study. Table 1 indicates the general information from the respondents for the study and their organisations.

Table 1: General information of the respondents for the study and their organisations

\begin{tabular}{lcc}
\hline Information & Frequency & Percentage \\
Gender of respondents & 45 & \\
Males & 5 & 90 \\
Females & & 10 \\
& 17 & \\
Age range of respondents & 20 & 30 \\
$21-30$ & 10 & 40 \\
$31-40$ & 3 & 20 \\
$41-50$ & & 6 \\
More than 50 & 1 & 2 \\
Educational level of respondents & 12 & 24 \\
Certificate & 32 & 64 \\
Diploma & 5 & 10 \\
Degree & & \\
Masters & & \\
&
\end{tabular}




\begin{tabular}{lcc}
\hline Work experience of respondents & 5 & \\
Less than 5 years & 17 & 34 \\
$6-10$ years & 20 & 40 \\
$11-15$ years & 8 & 16 \\
$16-20$ years & & \\
& 15 & 30 \\
Position of respondents & 10 & 24 \\
Directors & 20 & 40 \\
Managers & 5 & 6 \\
Supervisors & & \\
Other sections & & \\
\hline
\end{tabular}

Males constitute $90 \%$ of the respondents for the study while females represent $10 \%$ of the respondents for the study. Although, the study is skewed towards the male respondents, it (the study) is not gender-based. The skewness of the respondents towards the male respondents can easily be linked to the domination of the construction industry by males especially in developing economies like Rwanda. According to the International Labour Organisation (2017), 5.5\% of women in Africa, 5.5\% of women in South America, 7.5\% of women in Western Europe, $11.7 \%$ of women in North America, 14.6\% of women in Asia, $19.4 \%$ of women in China, $12.25 \%$ of women in Sri Lanka, and 17.9\% of women in Thailand are in paid construction employment across the globe. This shows that only China and Thailand are close to $20 \%$ of women in paid construction employment in the world. This further clarifies the reason for the male domination of studies in the construction industry.

Also, $30 \%$ of the respondents for the study were between ages $21-30$ years, $40 \%$ were between $31-40$ years, $20 \%$ were between ages $41-50$ years and only $6 \%$ were more than 50 years of age. This shows that many respondents of the study were in their youthful ages. The investigation of the educational qualification of the respondents show that $2 \%$ had certificate qualification, $24 \%$ had diploma, $64 \%$ had Bachelor's degree and 2\% had Master's degree. This indicates that $70 \%$ of the respondents were well educated up to the Bachelor's degree level. Despite the educational level of the respondents, the study went further to investigate their work experience. This, $10 \%$ had below 5 years of experience, $34 \%$ had between 5 and 10 years of experience, $40 \%$ had between 11 and 15 years of work experience, and $16 \%$ had between 16 and 20 years of work experience. This indicates that $90 \%$ of the respondents used for this study had more than 5 years of work experience and could provide valuable information for the study. Lastly, $30 \%$ of the respondents were directors in their organisations, $24 \%$ were at managerial levels, $40 \%$ were supervisors and $6 \%$ were in other sections of their organisations. With this 
information, it could be deduced that $94 \%$ of the respondents were at the top levels of their organisations and were responsible for determining who is recruited in their organisations.

Table 2 indicates the prevalent recruitment and selection strategies adopted by construction employers in Rwanda. The strategies investigated in the study were obtained from the literature used to conduct this study. The prevalence of the strategies was measured with 5 point Likert scale of $1=$ not prevalent to $5=$ very prevalent. The mean item score was determined with cut point values of $1.0-1.49=$ not prevalent, $1.5-2.49=$ slightly prevalent, $2.5-3.49=$ averagely prevalent, $3.5-4.49=$ prevalent and $4.5-5.0=$ very prevalent. The most prevalent recruitment and selection strategies adopted by construction organisations are requesting for curriculum vitae of applicants along with cover letter ( $4.9=$ very prevalent) and face-to-face interview (4.5 $=$ very prevalent). In addition, submitting applications with key information of education/work experience (4.18) and knowledge test to measure job specific knowledge (3.84) were found to be prevalently used by construction organisations in Rwanda.

The strategies that were averagely prevalent in the Rwandan construction industry include description and justification of the method to be used for recruitment and selection (2.92), personality and interest tests for applicants (2.8), evaluation of training and experience though the use of checklists (2.72), personal profile and biographical data checking (2.84), improvement of interview skills by organisation's human resources personnel (3.06), identifying and listing key selection criteria to be considered for a position (3.4), and maintenance of good relationship with employees that have previously worked in a firm (3.36). Also, behavioural interviews to ascertain specific samples of applicants' skills (2.46), hiring from a broad range of backgrounds (1.52), giving attention to applicants' references (2.26) and carefully screening job applicants were slightly prevalently used by construction organisations in Rwanda for recruitment and selection. Finally, the construction organisations in Rwanda do not use results of medical examination on fitness test (1.3), applicants' pool (1.28), group interview (1.3), performance test under structured challenging circumstances (1.16), physical or technical abilities (1.32), informing the community about vacancy or plans to recruit (1.26) for recruitment and selection. 
Table 2: Prevalent recruitment and selection strategies in the construction industry

\begin{tabular}{|c|c|c|c|}
\hline Recruitment and selection strategies & $\begin{array}{l}\text { Mean } \\
\text { Score }\end{array}$ & Rank & Remark \\
\hline Asking for Curriculum vitae along with application & 4.90 & 1 & Very prevalent \\
\hline Face to face individual interview & 4.50 & 2 & Very prevalent \\
\hline $\begin{array}{l}\text { Submitting applications with presenting key information of } \\
\text { education/ work experience }\end{array}$ & 4.18 & 3 & Prevalent \\
\hline Knowledge tests to measure the job-specific knowledge & 3.84 & 4 & Prevalent \\
\hline $\begin{array}{l}\text { Identifying and listing the key selection criteria to be } \\
\text { considered for the position }\end{array}$ & 3.40 & 5 & Averagely prevalent \\
\hline $\begin{array}{l}\text { Maintaining a good relationship with employees who have } \\
\text { been in the firm previously }\end{array}$ & 3.36 & 6 & Averagely prevalent \\
\hline Improved interview skills & 3.06 & 7 & Averagely prevalent \\
\hline Personal profile or biographical data checking & 2.84 & 8 & Averagely prevalent \\
\hline Personality and interest test & 2.80 & 9 & Averagely prevalent \\
\hline $\begin{array}{l}\text { Evaluation of training and experiences through provision of } \\
\text { checklist }\end{array}$ & 2.72 & 10 & Averagely prevalent \\
\hline $\begin{array}{l}\text { Behavioral interviews to ascertain specific samples of their } \\
\text { skills }\end{array}$ & 2.46 & 11 & Slightly prevalent \\
\hline Creating the right job posting & 2.30 & 12 & Slightly prevalent \\
\hline Give value to provided references & 2.26 & 13 & Slightly prevalent \\
\hline Carefully screened job applicants & 2.18 & 14 & Slightly prevalent \\
\hline Hiring from a broad range of Background & 1.52 & 15 & Slightly prevalent \\
\hline $\begin{array}{l}\text { Ability to tests and measure mental, clerical, mechanical, } \\
\text { physical or technical abilities }\end{array}$ & 1.32 & 16 & Not prevalent \\
\hline Group interview & 1.30 & 17 & Not prevalent \\
\hline Medical examination to test physical fitness & 1.30 & 18 & Not prevalent \\
\hline Building an applicants' pool & 1.28 & 19 & Not prevalent \\
\hline Inform your surrounding community about the plan to recruit & 1.26 & 20 & Not prevalent \\
\hline Performance test under structured challenging circumstances & 1.16 & 21 & Not prevalent \\
\hline
\end{tabular}

Cut point: $1.0-1.49=$ Not prevalent, $1.5-2.49=$ Slightly prevalent, $2.5-3.49=$ Averagely prevalent, $3.5-4.49=$ Prevalent and $4.5-5.0=$ Very prevalent

Table 3 shows the frequency of use of the sources from which construction organisations in Rwanda do recruitment and selection of their employees. The level of use of the identified sources were calibrated from $1=$ not used to $5=$ well used. Hence, internship performance 
advantage (4.6) and internal advertisement (4.8) were the well-used sources of recruitment and selection by construction organisations.

Table 3: Level of use of the sources of recruitment and selection in the construction industry

\begin{tabular}{|c|c|c|c|c|}
\hline $\begin{array}{l}\text { Sources of recruitment and } \\
\text { selection }\end{array}$ & Mean score & $\begin{array}{l}\text { Rank within } \\
\text { class }\end{array}$ & Overall rank & Remark \\
\hline \multicolumn{5}{|l|}{ Internal sources } \\
\hline Internal advertisement & 4.80 & 1 & 1 & Well used \\
\hline Internship performance advantage & 4.60 & 2 & 2 & Well used \\
\hline Present employees & 4.00 & 3 & 6 & Used \\
\hline Promotions & 3.62 & 4 & 8 & Used \\
\hline Transfers & 2.18 & 5 & 13 & Slightly used \\
\hline \multicolumn{5}{|l|}{ External sources } \\
\hline $\begin{array}{l}\text { Recommendation of existing } \\
\text { employees }\end{array}$ & 4.26 & 1 & 3 & Used \\
\hline Former employees & 4.10 & 2 & 4 & Used \\
\hline Local Newspaper advertisement & 4.08 & 3 & 5 & Used \\
\hline Educational institutions & 3.84 & 4 & 7 & Used \\
\hline Word of Mouth & 3.24 & 5 & 9 & Averagely used \\
\hline Professional associations & 2.96 & 6 & 10 & Averagely used \\
\hline $\begin{array}{l}\text { Direct mail to prospective } \\
\text { candidates }\end{array}$ & 2.52 & 7 & 11 & Averagely used \\
\hline Walk-in interviews & 2.20 & 8 & 12 & Slightly used \\
\hline Internet recruitment & 1.94 & 9 & 14 & Slightly used \\
\hline Company website & 1.92 & 10 & 15 & Slightly used \\
\hline Government Job Centers & 1.82 & 11 & 16 & Slightly used \\
\hline Job fairs & 1.56 & 12 & 17 & Slightly used \\
\hline Talent hunting & 1.48 & 13 & 18 & Not used \\
\hline E-recruitment & 1.40 & 14 & 19 & Not used \\
\hline Employment agents & 1.10 & 15 & 20 & Not used \\
\hline
\end{tabular}

Cut point: $1.0-1.49=$ Not used, $1.5-2.49=$ Slightly used, $2.5-3.49=$ Averagely used, $3.5-4.49=$ Used and $4.5-5.0=$ Well used 
Furthermore, local newspaper advertisement (4.08), references from former employees/employment of former employees (4.1), recommendation of existing employees (4.26), recommendation from educational institutions (3.84), recommendation by present employees $(4,0)$ and promotion of internal staff (3.62) fell under used sources of recruitment and selection of employees by construction organisations. Recommendations by professional institutions (2.96), word of mouth (3.24) and sending of direct mails to prospective candidates (2.52) were averagely used sources of recruitment and selection by construction organisations. The sources that were slightly used include internet recruitment (1.94), applications via company websites (1.92), government job centres (1.82), walk-in interviews (2.2), job fairs (1.56) and transfer between companies (2.18). Employment agents (1.1), talent hunting (1.48) and e-recruitment (1.4) were not used sources of recruitment by construction organisations in Rwanda.

Having identified the level of use of the sources of recruitment and selection by construction organisations in Rwanda, the study investigated the effectiveness of the sources as perceived by the recruiting organisations as depicted in Table 4 . The effectiveness was measured with a five point Likert scale of $1=$ not effective to $5=$ very effective. Hence, none of the sources was found to be very effective. However, the effective sources of recruitment and selection include recommendation or employment from former employees (3.66), recommendation of existing employee (4.18), recommendation from educational institutions (3.7), direct mails to prospective candidates (3.92), internship performance advantage (4.48), internal advertisement (4.4), present employees (4.28) and promotions (3.8). The averagely effective sources of recruitment are internet recruitment (3.06), applications via company's websites (3.4), recommendation from professional associations (3.44) and word of mouth (3.26). The slightly effective sources of recruitment are local newspaper advertisement (2.46), government job centres (2.06), e-recruitment (2.06), walk-in interview (1.76) and transfer between companies (2.0). The sources that are not effective are employment agents (1.08), talent hunting (1.44) and job fairs (1.44).

Table 4: Effectiveness of the sources of recruitment and selection in the construction industry

\begin{tabular}{|l|c|c|c|l|}
\hline $\begin{array}{l}\text { Sources of recruitment and } \\
\text { selection }\end{array}$ & Mean score & $\begin{array}{c}\text { Rank within } \\
\text { class }\end{array}$ & Overall rank & Remark \\
\hline Internal sources & & & & \\
\hline Internship performance advantage & 4.48 & 1 & 1 & Effective \\
\hline
\end{tabular}




\begin{tabular}{|c|c|c|c|c|}
\hline Internal advertisement & 4.40 & 2 & 2 & Effective \\
\hline Present employees & 4.28 & 3 & 3 & Effective \\
\hline Promotions & 3.80 & 4 & 6 & Effective \\
\hline Transfers & 2.00 & 5 & 16 & Not effective \\
\hline \multicolumn{5}{|l|}{ External sources } \\
\hline $\begin{array}{l}\text { Recommendation of existing } \\
\text { employees }\end{array}$ & 4.18 & 1 & 4 & Effective \\
\hline $\begin{array}{l}\text { Direct mail to prospective } \\
\text { candidates }\end{array}$ & 3.92 & 2 & 5 & Effective \\
\hline Educational institutions & 3.70 & 3 & 7 & Effective \\
\hline Former employees & 3.66 & 4 & 8 & Effective \\
\hline Professional associations & 3.44 & 5 & 9 & Averagely effective \\
\hline Company website & 3.40 & 6 & 10 & Averagely effective \\
\hline Word of Mouth & 3.26 & 7 & 11 & Averagely effective \\
\hline Internet recruitment & 3.06 & 8 & 12 & Averagely effective \\
\hline Local Newspaper advertisement & 2.46 & 9 & 13 & Slightly effective \\
\hline Government Job Centers & 2.06 & 10 & 14 & Slightly effective \\
\hline E-recruitment & 2.06 & 11 & 14 & Slightly effective \\
\hline Walk-in interviews & 1.76 & 12 & 17 & Slightly effective \\
\hline Job fairs & 1.44 & 13 & 18 & Not effective \\
\hline Talent hunting & 1.44 & 14 & 19 & Not effective \\
\hline Employment agents & 1.08 & 15 & 20 & Not effective \\
\hline
\end{tabular}

Cut point: $1.0-1.49=$ Not effective, $1.5-2.49=$ Slightly effective, $2.5-3.49=$ Averagely effective, $3.5-4.49=$ effective and $4.5-5.0=$ Very effective

\section{Discussion of findings}

The study investigated the various strategies that are adopted by construction employers for the recruitment and selection of construction workers in Rwanda. The prevalent recruitment and selection strategies, prominent sources of recruitment and selection and the effectiveness of the sources of recruitment and selection in the Rwandan construction industry were the objectives of the study.

The finding of the study indicated that the prevalent strategies of recruiting and selecting staff into the construction industry are requests for the curriculum vitae of applicants along with cover letter, face-to-face interview, submission of applications with key information of 
education/work experience and knowledge test to measure job specific knowledge. Also, description and justification of the method to be used for recruitment and selection, personality and interest tests for applicants, evaluation of training and experience through the use of checklists, personal profile and biographical data checking, improvement of interview skills by organisation's human resources personnel, identification and listing of key selection criteria to be considered for a position and maintenance of good relationship with employees that have previously worked in a firm were averagely prevalent recruitment and selection strategies into the construction industry. Although, previous studies checked were mostly from other industries apart the construction industry due to the scarcity of similar studies in the construction industry, the findings are in agreement with Langseth, (1995) on carefully screening of job applicants, maintenance of good relationship with previous employees of the firm and Hornberger (1998) on improvement of organisation's interviewer skills.

The study also agrees with the findings of Jyoth (2006) on hiring from internal applicants, evaluation of training and experiences through provision of checklist, asking for curriculum vitae along with application, submission of applications with key information of education/work experience, personality and interest tests for applicants, knowledge tests to measure the job-specific knowledge, behavioural interviews to ascertain specific skills and face-to-face individual interview. However, the study disagrees with previous findings in the area of giving value to potential employees' references and previous employments (Odiorne, 1984), informing the surrounding community about the plan to recruit (Prashant, 2009), creation of the right job posting which includes details of the type and quality of skills required (Mathis and Jackson, 2006), building applicants' pool/employee referral program (Jyoth, 2006) and hiring from a broad range of background (Cuming, 1994). The reasons for the similarities in the findings may be due to the general principles of employment regardless of the field involved and the differences may be due to the peculiarities of the industries involved and differences in cultural backgrounds of the studies.

Similarly, the prominent sources of recruitment and selection according to the study are internship performance, internal advertisement, local newspaper advertisement, references from former employees/employment of former employees, recommendation of existing employees, recommendation from educational institutions, recommendation by present employees, and promotion of internal staff, recommendations by professional institutions, word of mouth and sending of direct mails to prospective candidates. The study is in agreement 
with previous studies in the area of promotions (Sherman et al. 1998), internal advertisement (Keshav, 2013), external advertisement (Rajarao, 2010), recommendation from educational institutions (Nel et al. 2009), Recommendation of existing employees (Rajarao, 2010) and former employees (Brake and Lawrence, 2000), employee referral (Sinha and Thaly, 2013). However, the study disagrees with previous studies in the area of transfers (Keshav, 2013), walk-in interviews, e-recruitment (Cappelli, 2001; Nel et al. 2009), campus recruitment, recruitment offices/advisors, work destinations/entries, and organisation's sites (Sinha and Thaly, 2013). Among these prominently used sources of recruitment and selection, none was found to be very effective. However, recommendation from former employees, recommendation of existing employee, recommendation from educational institutions, direct mails to prospective candidates, internship performance advantage, internal advertisement, present employees and promotions were found to be effective. Although not prominently used, internet recruitment, applications via company's websites, recommendation from professional associations and word of mouth were noted to be averagely effective.

\section{CONCLUSION OF THE STUDY}

This study investigated the strategies of recruitment and selection, the sources of recruitment and selection and their effectiveness in the Rwandan construction industry. The variables used for the study were obtained from similar studies that have been conducted in the fields of marketing, manufacturing, services and communication among others. The quantitative descriptive research technique was used for the study and the questionnaire for the study was based on a 5-point Likert scale and divided into two sections (specific and general).

The result of the study indicated that the prevalent strategies adopted by construction organizations to recruit and select workers are through the use of applicants' curriculum vitae along with cover letter, face-to-face interview, submission of applications with key information of education/work experience, knowledge test to measure job specific knowledge, description and justification of the method to be used for recruitment and selection, personality and interest tests for applicants, evaluation of training and experience through the use of checklists, personal profile and biographical data checking, improvement of interview skills by organisation's human resources personnel, identification and listing of key selection criteria for a position and maintenance of good relationship with employees that have previously 
worked in a firm. These results are in agreement with previous studies and this shows that the strategies of recruiting and selecting workers are similar across all industries.

Furthermore, the study indicated that the prominently used sources of recruitment are internal advertisement, internship performance advantage, promotions and recommending existing employees among others. Among the sources of recruitment and selection, respondents agreed that internship performance, internal advertisement, local newspaper advertisement, references from former employees/employment of former employees, recommendation of existing employees, recommendation from educational institutions, recommendation by present employees, and promotion of internal staff, recommendations by professional institutions, word of mouth and sending of direct mails to prospective candidates were effective sources of recruitment and selection of workers. These results are also in agreement with previous studies to a large extent.

It could be observed that some of the used sources of recruitment and selection were rated as being ineffective by the respondents of this study. However, the reasons for using the less effective sources of recruitment and selection by construction organisations is not investigated in this study. Therefore, it is suggested that this aspect of the study be subjected to further study.

From the results of the study, it appears the most effective sources of filling a vacant position in a construction organisation is the employment of known people such as former internship students, internal application, recommendation from educational institutions, and promotion of an internal staff among others. Hence, the study recommends that these sources should be properly harnessed by appropriate record keeping and selection procedure. The possibility of combining more than one method should be considered for effective result.

\section{REFERENCES}

Adienge, O., Ogolla, D., and Senaji, T. A. (2018). Relationship between recruitment practices and performance of county governments in Kenya. The Strategic Journal of Business and Change Management, 5 (3) 705 - 717

Cappelli, P. (2001). The National Employer Survey: Employer Data on Employment Practices. Industrial Relations, 40 (2) 635-647 
Cuming, M. W. (1994). The theory and practice of personnel management. Seventh edition. Butterworth: Heinemann

Djabatey E. N. (2012). Recruitment and selection practices of organizations: A case study of HFC Bank (GH) Ltd. Unpublished thesis submitted to the Institute of Distance Learning, Kwame Nkrumah University of Science and Technology. Ghana: Kwame Nkrumah University of Science and Technology.

Duggan, B. and Croy, G. (2004). Should you outsource recruitment? Emerald Management Review: Supply Management Edition, South-Western Educational Publishing Ekwoaba, J.O. Ikeije, U.U., and Ufoma, N. (2015). The Impact of Recruitment and Selection Criteria on Organizational Performance. Global Journal of Human Resource Management, 3 (2) 22-33

Gomez-Mejia, L. R., Balkin, D. B. and Cardy, R. L. (2004). Managing Human Resources. Hornberger, F. (1998). "When and Why Contractors Use Executive Recruiters" FMI Contractors Management Journal. December 1998, p. 9-11. Human resource management: Theory and practice (4th edition), (pp.358-400).

István, J. (2010). Selection methods used in recruiting sales team members. Periodica Oeconomica, 110-117.

Jyoth, P. Venkatesh, D, N. (2006). Human Resource Management, New Delhi. Keshav, P., (2013). Internal Sources and Methods of Recruitment. Chichester, Wiley Langseth, P. (1995) Civil Service Reform in Uganda: Les sons Learned. Public Administration and Development 15.1: 365-90. http://dx.doi.org/10.1002/pad.4230150403

Lushiku, L. (2014). Assessment on the effectiveness of recruitment and selection process in public sectors: A case of Tanzania Revenue Authority (TRA). Master's Dissertation at Mzumbe University, Dar-es-Salaam.

Mathis, R. and Jackson, J. (2006). Human Resource Management (15 $5^{\text {th }}$ edition) Mason, OH: Thomson/Southwestern, 524-565

MININFRA (2015). MININFRA action plan 2015-16 for MININFRA lead ministry. Accessed on $10^{\text {th }}$ July 2020 at https://www.mininfra.gov.rw/.../MININFRA_Lead_MINISTRY_SINGLE_ ACTION_PLAN_SAP_Final_Version-_RBM_based.pdf

National Institute of Statistics, Rwanda (2019). Statistical reports. Accessed on $5^{\text {th }}$ April 2021 at www.statistics.gov.rw/statistical-publications/subject/...statistics/reports 
Nel, P. S., Werner, A., Haasbroek, G. D., Poisat, P., Sono, T., and Schuiltz, H. B. (2009). Human resource management. (7th ed.). Cape Town: Oxford University Press.

Odiorne, G. S. (1984). Human Resource Strategies Hax.

Prasad, L. M (2006). Human Resource Management. Sultanchand and Sons: Educational Publishers

Prashant, A. (2009). Human resource management: Recruitment the challenge: Sources of recruitment.

Rajarao, H. K. (2010). Introduction to human resource management. New Delhi. India.

Robbins, S. P. (2005). Organizational behaviour: Concepts, controversies and applications. New Jersey: Prentice Hall

Rotella, Katie (2000). The Joys of E-Recruiting. Plumbing and Mechanical. 16, 26-35.

Schuler, R. and Jackson, S. (1987). Linking Competitive Strategies with Human Resource Management Practices. The Academy of Management Executive, 207-219. DOI: 10.5465/AME.1987.4275740

Sherman, A. W. Bohlander G. W. and Snell S. A., (1998), Managing Human Resources, 11th Edition, South-Western Educational Publishing

Sinha, V. and Thaly, P. (2013). A review on changing trend of recruitment practice to enhance the quality of hiring in global organizations. Management, 18 (2), 141-156.

Sutherland, J. and Diane Canwell, D. (2008) Essential Business Studies A Level: AS Student Book for $A Q A$, Folens Publications

Tansley, C., Newell, S. and William, H. (2001). Effecting HRM-Style Practices through an Integrated Human Resource Information System: An E-Greenfield Site? Personnel Review, 30, 351-371

Wilkinson, A. (2004). Downsizing, Rightsizing or Dumbsizing?: Quality and Human Resources, in the Management of Sustainability. Total Quality Management Journal, $1-18$ 